\title{
The Influence of Brand Ambassador Agnez Mo on Lazada Consumer Purchase Intention in Bandung City
}

\author{
Shandra Okta Lista ${ }^{1}$, Nuslih Jamiat ${ }^{2}$ \\ Telkom University \\ Faculty of Communication and Business \\ Bandung \\ shandraoktalista@student.telkomuniversity.ac.id \\ nuslihjamiat@telkomuniversity.ac.id
}

\begin{abstract}
This study was conducted to determine the effect of Agnez Mo as a Brand Ambassador on consumer buying interest at Lazada in the city of Bandung. This study aims to determine and analyze how Lazada consumers respond to the Brand Ambassador in Lazada, how the consumer's buying interest in Lazada, the magnitude of the influence of the Lazada Brand Ambassador on consumer buying interest in Lazada Bandung City. This research uses a quantitative method with a descriptive research type. The sampling technique was carried out using a non-probability sampling method with purposive sampling type, with a total of 100 respondents. The data analysis technique used is descriptive analysis and simple regression analysis. Based on the results of partial hypothesis testing (t-test) it was found that the Lazada Brand Ambassador variable had a significant negative effect on consumers' buying interest in Lazada Bandung City. This is evidenced by hypothesis testing showing that the Brand Ambassador variable (X) has a value of t-count $(-4.167)<\mathrm{t}$-table $(-1.984)$ and a significance level of $0.000<0.05$. Based on the coefficient of determination, it is found that the influence of the Brand Ambassador variable $(\mathrm{X})$ on Purchase Interest $(\mathrm{Y})$ is $15 \%$. The conclusion of this study, the influence of the Lazada Brand Ambassador is in a bad category and has a significant negative effect on the buying interest of Lazada consumers in Bandung City.
\end{abstract}

Keyword: brand ambassador, consumer behavior, purchase intention.

\section{INTRODUCTION}

\subsection{Background}

In today's digital era that is growing rapidly and technological advances can influence consumer behavior that needs something instantly, one example of technology in the digital era is online trading or e-commerce. According to Laudon and Traver (2017:8), describing-commerce is the use of the internet, networks, and applications, and browsers that run through devices to enable business transactions between organizations and individuals or between individuals and others. According to data from Iprice in the 4th quarter of 2018 Lazada has 58.2 million web visitor data. In the second quarter of 2019 , it was still the same as the previous year, which was still in the fourth position but there was a decrease in the number of visitors with a total of 49.6 million visitors. In the fourth quarter of 2019, it was still in the fourth position, the same as the two previous years, with a total of 28.3 million visitors. And in the 2 nd quarter of 2020 with a total of 22 million visitors, it decreased and in the 3rd quarter of 2020, there was an increase in the number of visitors reaching 22.6 million. This is where the position does not change from year to year, but Lazada has tried to increase the number of web visitors and e-commerce position to excel from the three e-commerce namely Tokopedia, Shopee, and Bukalapak.

So in connection with this, Lazada needs to carry out a strategy to stay competitive with other e-commerce competitors, namely a marketing strategy is needed. One of them is promotion. The promotional mix according to Kotler and Keller (2016: 582) is the promotion mix or the promotion mix is the best strategy combination of promotional elements used to achieve company goals. These elements are tools of the company's marketing communicators in communicating with customers. One of them is by using Brand Ambassador. According to Sadrabadi et al (2020:22) defines "brand ambassador is a mediator between internal and external brand management and can have a significant impact on customer perception of brands and organizations; and in 
general, the brand ambassadors are brand representatives who confirm brands by their reputation". What this means is that brand ambassadors are mediators between internal and external brand management and can have a significant impact on customers' perceptions of brands and organizations; and in general, a brand ambassador is a brand representative who confirms a brand based on its reputation. This is done to be able to promote their products to the wider community, which is expected to convey the information and can attract the attention of consumers to have an interest in buying on Lazada. According to Priansa (2017:164), buying interest is focusing on something that is accompanied by feelings of pleasure for the item, and then this personal interest will cause a desire so that the individual needs for remuneration or exchange of money to the owner of the item. And the use of Lazada Brand Ambassador costs to pay for the advertisement, according to "Adstensity" Lazada's advertising cost ranks sixth.

However, his efforts could not significantly increase the number of visitors from the Lazada web compared to other e-commerce, where Lazada's position is still in the last position and is also supported by data regarding the most recommended e-commerce competition map which is still far from the Lazada company's expectations.

\subsection{Problem Formulation}

Based on the above phenomenon, the writer wants to investigate further about Brand Ambassador and Buying Interest with a research entitled "The Influence of Agnez Mo's Brand Ambassador on Consumer Buying Interest at Lazada in Bandung City". The formulation of the problem in this study is as follows:

1. How do consumers respond to Brand Ambassadors at Lazada?

2. How is the consumer's buying interest in Lazada?

3. How much influence does the Brand Ambassador have on consumer buying interest in Lazada?

\subsection{Research Objectives}

This study aims to examine and analyze the relatisnship between research variables operation, a hat can be done through empirical testing against several variables as follows:

1. Knowing consumer responses to brand ambassadors in Lazada.

2. Knowing consumer buying interest in Lazada.

3. Knowing the influence of brand ambassadors on consumer buying interest in Lazada.

\section{LITERATURE REVIEW}

\subsection{Promotion}

Fandy Tjiptono (2019: 387) defines promotion as an element of the marketing mix and focuses on efforts to inform, persuade, and remind consumers of the company's brands and products.

\subsection{Promotion Mix}

According to Kotler and Keller (2016: 582), the promotion mix is the best combination of promotional element strategies used to achieve company goals. These elements are tools for the company's marketing communicators to communicate with customers.

\subsection{Advertising}

According to Tjiptono (2019), advertising is a form of promotion of ideas for goods or services in any form through print media advertisements, online media advertisements, electronic media advertisements, posters, brochures, and other media.

\subsection{Brand Ambassador}

Kertamukti (2015: 69) says that celebrities are famous for their achievements in various fields of the product groups they support. Their participation is often referred to as a brand endorser or brand ambassador. According to Kertamukti (2015: 69), rising celebrities will be selected first, the question is whether the chosen celebrity can represent the characteristics of the advertised product. Second, of course, related to the company's finances, it is hoped that celebrities can be the spokespersons for the brand.

\subsection{Consumer behavior}

According to Firmansyah (2019:2), consumer behavior is related to activities in the process of buying, searching, researching, and evaluating products or services. It can be said that consumer behavior is making purchasing decisions based on being a consumer.

\subsection{Buying Interest}

According to Schiffman and Kanuk (2017: 64), buying interest is the attitude that a person has when considering objects such as certain products, services, and brands that they consider appropriate to buy.

\subsection{Relation of Brand Ambassador and Purchase Intention}

According to Kertamukti (2015: 32), as a tool to attract attention, brand ambassadors must use attractive models or celebrities as brand ambassadors. If consumers feel that the star of the advertisement does not match the product being promoted, the dangers of using the model as a spokesperson will be affected.

H1: The Brand Ambassador Agnez Mo variable has an effect on the Purchase Interest Variable on consumers at Lazada.

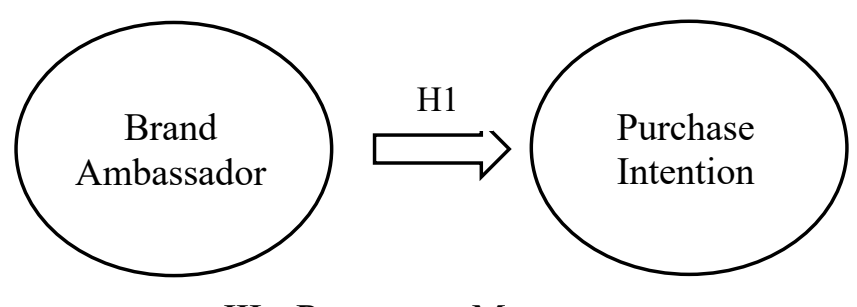

III. RESEARCH METHODS

This study uses a quantitative approach with a descriptive method. The measurement scale used in this study is the 
Likert scale. The population in this study used is the people of the city of Bandung who has used the Lazada application, whose exact number is not known. In this study, the sampling technique used is a non-probability sampling technique using the sampling method used is Purposive Sampling. The number of samples that were successfully obtained were 100 people who were calculated using the Bernoulli formula with an error tolerance level of $10 \%$. The data analysis technique used descriptive analysis using SPSS (Statistical Package for Social Science) version 26.

\section{RESULTS AND DISCUSSION}

The discussion about the characteristics of respondents in this study consisted of gender, age, profession, and monthly income, can be seen in the table below:

Table 1. Respondent Characteristics

\begin{tabular}{|c|c|}
\hline Characteristic & Frequency \\
\hline \multicolumn{2}{|l|}{ Gender } \\
\hline Male & 58 \\
\hline female & 42 \\
\hline \multicolumn{2}{|l|}{ age } \\
\hline Under 19 & \\
\hline $19-25$ & 49 \\
\hline $25-30$ & 29 \\
\hline $31-35$ & 13 \\
\hline 36 & 4 \\
\hline 37 & 1 \\
\hline 38 & 2 \\
\hline 39 & 1 \\
\hline \multicolumn{2}{|l|}{ Profession } \\
\hline Student & 57 \\
\hline Employee & 26 \\
\hline Entrepreneur & 17 \\
\hline \multicolumn{2}{|l|}{ Monthly Income } \\
\hline Under 1 Million & 24 \\
\hline 1 Million -3 Million & 40 \\
\hline 3 Million - 5 Million & 21 \\
\hline Above 5 Million & 15 \\
\hline
\end{tabular}

The results of the descriptive analysis technique show respondents' responses to the Brand Ambassador variable with a total score of 2,820 with a percentage of $51.27 \%$ and are included in the bad category on the continuum line. Meanwhile, the Purchase Interest variable (Y) gets a total score of 2,473 with a percentage of $61.83 \%$ and is included in the fairly good category on the continuum line.
Table 2. Regression Analysis

\begin{tabular}{|c|c|c|c|c|}
\hline \multicolumn{5}{|c|}{ Coefficients } \\
\hline \multirow{2}{*}{\multicolumn{2}{|c|}{ Model }} & \multicolumn{2}{|c|}{$\begin{array}{c}\text { Unstandardized } \\
\text { Coefficients }\end{array}$} & \multirow{2}{*}{$\begin{array}{c}\begin{array}{c}\text { Standardiz } \\
\text { ed }\end{array} \\
\text { Coefficients } \\
\\
\text { Beta }\end{array}$} \\
\hline & & $\mathrm{B}$ & $\begin{array}{l}\text { Std. } \\
\text { Error }\end{array}$ & \\
\hline \multirow[t]{2}{*}{1} & (Constant) & 4.625 & .212 & \\
\hline & $\begin{array}{l}\text { Brand } \\
\text { Ambassad } \\
\text { or }\end{array}$ & -.277 & .067 & -.388 \\
\hline
\end{tabular}

Simple Regression Analysis is used to determine the effect of the Independent Variables (Brand ambassadors) on the Bound Variable (Purchase Interest). The aim is to estimate the value of the Brand Ambassador variable in a causal relationship to the Purchase Interest variable.In the table below, the equation $\mathrm{Y}=4.625+(-0,277) \mathrm{X}+10 \%$. Constant $(\alpha)=4.625$. That is, if the Brand Ambassador value is 0 , then Buying Interest has a value of 4.625. The regression coefficient value of the Brand Ambassador variable (X) is negative, that is $(-0.277)$. This means that for every one unit increase, Purchase Interest will decrease by $(-0.277)$.

Table 3. t-Test Result

\begin{tabular}{|c|c|c|c|c|c|}
\hline \multicolumn{6}{|c|}{ Coefficients } \\
\hline \multirow[b]{4}{*}{ Model } & \multirow{2}{*}{\multicolumn{2}{|c|}{$\begin{array}{c}\text { Unstandardized } \\
\text { Coefficients }\end{array}$}} & \multirow{2}{*}{$\begin{array}{l}\text { Standardized } \\
\text { Coefficients }\end{array}$} & \multirow[b]{4}{*}{$\mathrm{t}$} & \multirow[b]{4}{*}{ Sig. } \\
\hline & & & & & \\
\hline & \multicolumn{3}{|c|}{ Std. } & & \\
\hline & B & Error & Beta & & \\
\hline 1 (Constant) & 4.625 & .212 & & 21,820 & .000 \\
\hline Brand & -.277 & .067 & -.388 & -4.167 & .000 \\
\hline Ambassador & & & & & \\
\hline
\end{tabular}

Based on the t-test, it can be seen that the value of the variable brand ambassador $(\mathrm{X})$ is t-count $(-4.167)<$ table $(-$ 1.984 ), and the significance level is $0.000<0.05$. 
Table 4. Determination Coefficient

\begin{tabular}{rr|r|r|r}
\hline \multicolumn{5}{c}{ Model Summary } \\
\hline Model & R & R Square & \multicolumn{1}{c}{$\begin{array}{c}\text { Sdjusted R } \\
\text { Square }\end{array}$} & $\begin{array}{c}\text { Std. Error of } \\
\text { the Estimate }\end{array}$ \\
\hline 1 & .388 & .150 & .142 & .42258 \\
& a & & & \\
\hline
\end{tabular}

a. Predictors: (Constant), Brand Ambassador

b. Dependent Variable: Buying Interest

Results calculation of the coefficient of determination, the value of the coefficient of determination is $15 \%$. This shows that the independent variable, namely the brand ambassador, has an effect of $15 \%$ on the dependent variable, namely buying interest, while the remaining $85 \%$ is influenced by other factors, such as the price factor which is not examined in this study.

\section{CONCLUSION}

Based on the results of research and discussion on the influence of Agnez Mo's brand ambassador on consumer buying interest in Lazada consumers, it can be concluded that researchers want something that is expected to be able to answer the questions formulated in this study. The conclusion is as follows:

1) Consumer responses to brand ambassadors at Lazada.

Based on the results of the Descriptive Analysis, based on respondents' responses, the Brand Ambassador (X) variable as a whole is in a Bad category. However, from the eleven statements that got the lowest score on the brand ambassador variable, it was "Agnez Mo can get me interested in Lazada ads and the ads are easier for me to remember", then it means that Agnez Mo cannot attract the attention of consumers to shop at Lazada.

\section{2) Consumer Buying Interest in Lazada}

Based on the results of the descriptive analysis, based on the respondents' responses, the overall buying interest variable is included in the category of good enough. However, from the eight statements regarding the Buying Interest variable, although it is still in the Good Enough category, the statement that gets the lowest score is "after seeing the ad on Lazada I intend to shop online at Lazada", then it means that Lazada consumers have no interest in buying at Lazada because of Agnez Mo.

\section{3) The Influence of Brand Ambassadors on Consumer} Buying Interest in Lazada.

Based on the results of the partial hypothesis test (t-test), the Brand Ambassador variable (X) has a tcount (-4.167) $<$ ttable $(-1.984)$ and a significance level of $0.000<0.05$, so $\mathrm{H} 0$ is rejected. Therefore, it can be concluded that there is a significant negative effect of the Brand Ambassador variable $(\mathrm{X})$ on the Purchase Interest variable (Y).

\section{REFERENCES}

[1] Firmansyah, MA, \& Se, M. (2019). Consumer Behavior (Attitude and Marketing). Publisher Qiara Media.

[2] Kertamukti, R. (2015). Creative Strategy In Advertising: Concept, Media, Branding, Budget. Jakarta: Rajawali Press.

[3] Kotler Philip, and KLK (2016). Marketing Management. Global Edition, 15 Edition. Essex, England: Pearson Education.

[4] Laudon, KC, \& Traver, CG (2017). E-commerce. Business. Technology. Society. New York: Pearson.

[5] Priansa, DJ . (2017). Consumer Behavior in Contemporary Business. Bandung: Alphabeta.

[6] Sadrabadi, AN, Saraji, MK, \& Monshizadeh, M. (2018). Evaluating the Role of Brand Ambassadors in Social Media. Journal of Marketing Management and Consumer Behavior.

[7] Schiffman L G. Dan Kanuk, L, L. (2017). Consumer Behavior (Tenth Edition). Tsinghua University Press. China.

[8] Sugiyono. (2018). Quantitative, Qualitative, and R\&D Research Methods. Bandung: Alphabeta.

[9] Tjiptono, Fandy. 2019. Marketing Strategy. 4th Edition. Yogyakarta :CV. ANDI OFFSET. 